\title{
Greek Perfects in Roman Epistolography ${ }^{\star}$
}

\author{
Maria N. Kazanskaya
}

Institute for Linguistic Studies of the Russian Academy of Sciences,

9, Tuchkov per., St. Petersburg, 199004, Russian Federation; subura@mail.ru

For citation: Maria N. Kazanskaya. Greek Perfects in Roman Epistolography. Philologia Classica 2020, 15 (1), 96-106. https://doi.org/10.21638/spbu20.2020.108

The perfect tense in Greek which is used to denote a state of affairs in the present as resulting from a past action does not find an exact equivalent in the system of Latin tenses: when faced with the need to express this idea a Latin speaker could either focus on the expression of the state by using the present tense (whereby the connection with the past was not expressed and would only be inferred), or use the perfect, in which case the effect of the past action on the present was not directly expressed and could only be deduced (the so-called resultative perfect). The article analyses Latin speakers' attitude to this difference between Greek and Latin verbal systems, in particular, on the basis of the evidence collected from Roman epistolography when the letter-writer felt that the idea he wished to express could most aptly be rendered by a Greek perfect and switched to the Greek solely for that perfect form. The corpus of texts used for this study included the letters of Cicero to Atticus and his Epistulae ad Familiares, the Letters of Pliny the Younger, Seneca's Letters to Lucilius, excerpts of Augustus' letters preserved by Suetonius, and M. Cornelius Fronto's correspondence with Marcus Aurelius.

Keywords: Greek perfect tense, Latin perfect tense, Roman epistolography, Greek and Latin bilingualism.

One of problems that scholars face when studying the history of the Greek perfect, the development of its usages and its place in the system of Greek tenses is the mapping out of the stages of the developments in the semantics of the perfect. ${ }^{1}$ The methodological difficulties that a scholar has to deal with, while detecting the shifts of the Greek perfect through literary sources, have been well summarized by McKay. ${ }^{2}$ There is, however, an aspect that has not been, it seems, sufficiently evoked in the discussion ${ }^{3}$ - namely, the question of how educated Romans, capable of speaking both Latin and Greek, viewed the Greek perfect. Indeed, the perfect tense in Greek, with its denotation of the present

* This study was conducted as part of the project "Expression of Perfectivity in Ancient IndoEuropean Languages and the Issues of proto-language Reconstruction" funded by the Russian Foundation for Basic Research (grant N 17-04-00228-OГH). An earlier version of this article was presented at the IndoEuropean seminar, hosted by the Institute for Linguistic Studies RAS (February 28, 2018). I am grateful to all participants of the seminar for their remarks that were of great help, when I was working on the article. I would also like to thank E. V.Zheltova and the anonymous reviewer for their insightful comments and helpful suggestions.

1 Wackernagel 1904; Wackernagel 1926-1928, I, 166-171; Chantraine 1926, esp. 146-190; McKay 1965; Schwyzer, Debrunner 1988, 263-164; Sicking, Stork 1996, 121-184; Rijksbaron 2007, 35-37.

2 See McKay 1965, 1-5.

${ }^{3}$ Roman views on Greek perfect are mentioned by J. Wackernagel 1926-1928, I, 187, but, for the most part, the use of the perfect tense in Greek of Hellenistic and Roman times has been discussed without taking into account the views of Latin speakers.

(C) St. Petersburg State University, 2020 
state, but with the idea that this state was conditioned by an action in the past, is one of the points where Latin and Greek verbal systems noticeably diverge. This is evident to any modern student of the ancient languages; it was, of course, evident to ancient bilingual speakers, capable of comparing the Greek and Latin, and in particular to grammarians whose teaching and explanation of Latin was very much founded on Greek grammatical theory. While the grammarians' theoretical approach to the semantics of Greek perfect can be reconstructed with a certain degree of detail, there is a group of passages that would reflect a bilingual speaker's approach to the discrepancy in the Greek and Latin verbal system as regards the Greek perfect and that has not received special attention: Roman epistolography preserves a number of examples where the writer uses a Greek perfect form, and in many of those cases, the switch to the Greek is made solely for this perfect form. Examples of such language switching for the sake of using a Greek perfect form do not seem to have ever been studied as a group, and this article proposes to analyze the occurrence of Greek perfects in Roman letter-writing in order to bring out certain tendencies in their use of these forms, which, in its turn, can provide us with an insight into the Latin speakers' views on the Greek perfect.

The fullest discussion of the use of Greek perfect in the Roman grammatical tradition appears in the Priscian's Institutio grammatica. Priscian (early 6th century AD) taught Latin grammar with special focus on syntax in Constantinople; ${ }^{4}$ his pupils were for the most part well educated Greek speakers, who already knew Latin and to whom he could explain the nuances of usage, comparing Latin and Greek languages and, in particular, their verbal systems:

sciendum, quod Romani praeterito perfecto non solum in re modo completa utuntur, in quo

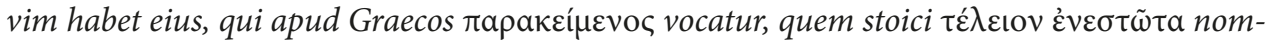
inauerunt, sed etiam pro ảopíotov accipitur, quod tempus tam modo perfectam rem quam multo ante significare potest (Prisc. Inst. 8. $54=$ GL II, 415 Keil).

It should be known that Romans use the perfect past tense not only for the just completed action, in which case it has the same force as the tense which is called by the Greeks

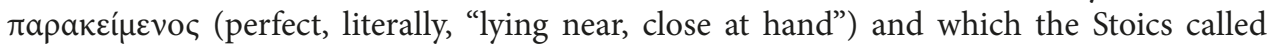

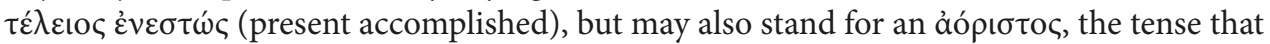
can denote an action just completed as well as one that $<$ has been completed $>$ much earlier. ${ }^{5}$

Explaining the use of perfect tense in Latin, Priscian identifies it with two tenses in Greek, the aorist (as expressing an action in the past) and the perfect (as designating a past action that is pertinent to the present). Priscian takes up the same idea in another passage of his Institutio grammatica dedicated to the comparison of the morphology of sigmatic aorists in Greek with that of sigmatic perfects in Latin (comparing, among others, $\kappa \rho v ́ \beta \omega-$

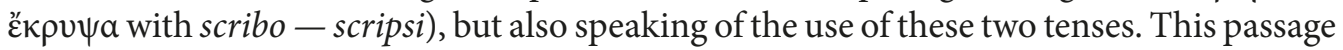

4 On the pivotal role of Priscian in drawing attention to questions of syntax, see Kaster 1997, 12; 196; for a general overview of what is known about him, see Helm 1954, 2328-2330; Glück 1967, 53-60; Kaster 1997, 346-348. The pedagogical reasons behind Priscian's regular comparison of Greek and Latin material (especially, of morphology and syntax) is evoked in a number of articles in the volume edited by Baratin, Colombat, Holtz (2009, 224; 323-324, etc.).

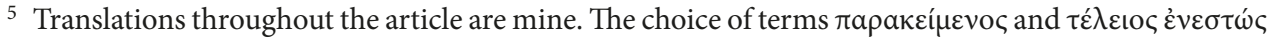

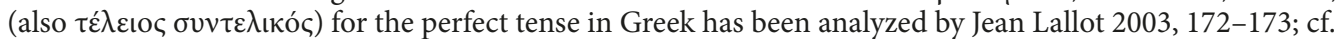

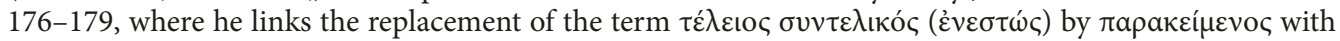
the idea that perfect denotes an action that has just been accomplished. 
is important because it also shows that the equivalence between the Latin perfect and the Greek aorist and perfect was introduced into the teaching of Latin long before Priscian:

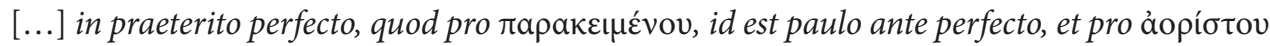

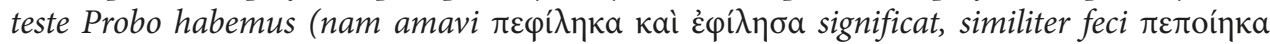

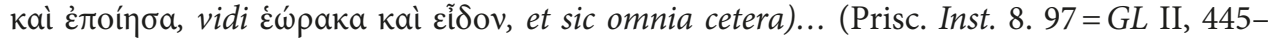
446 Keil).

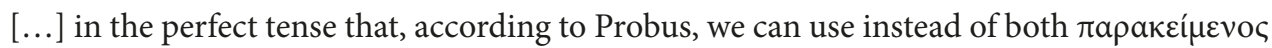

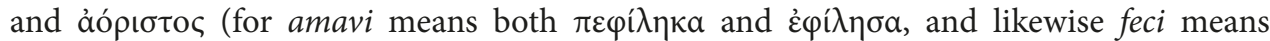

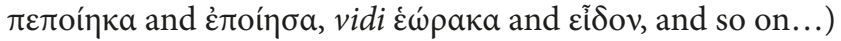

While Priscian's immediate aims in this passage do not leave him the space to elaborate on the correspondence of Greek and Latin tenses, this necessarily brief formulation invites him to illustrate the usage with examples, which is valuable for us. And the reference to M. Valerius Probus (20/30-105 AD) shows that the correspondence of Greek and Latin system of tenses was established in the teaching of grammar long before his time - certainly by early Imperial times, but more probably already in the Late Republic.

Unfortunately, ancient sources preserve no direct statement concerning the choice of Latin tenses to render the Greek perfect; however, the approach of Roman grammarians to this question may be deduced from their practice of translation. Seeing that translating Greek oratory, philosophy and even poetry was an exercise recommended as part of an orator's training, ${ }^{6}$ tendencies as to the choice of tenses observed in translations must reflect a well-established theoretical approach to the rendering of Greek perfect in Latin. Thus, as Ch. H. Saylor has shown in his overview of Cicero's use of tenses in passages translated from the Greek, of the thirty examples of perfect tense in Greek phrases rendered by Cicero into Latin, twenty-eight are rendered by the present tense, and the remaining two appear in subordinate clauses which require the subjunctive in Latin. ${ }^{7}$

A look at ancient theory and the ancient practice of translation shows that for ancient speakers the Latin Perfect corresponded to the Aorist and to the Perfect tense in Greek, whereas the Greek Perfect corresponded to the Latin Present. Despite this established view, in live speech the Romans seem to have felt the lack of a tense in Latin which would correspond to the semantic richness of the Greek perfect. Examples of this sort can be found in epistolography, the genre aiming at reproducing the nuances of intimate, unofficial speech. Cicero's letters to Atticus and the Epistulae ad familiares, the small number of extracts from emperor Augustus' correspondence preserved in Suetonius, Seneca's Letters to Lucilius, and Fronto and Marcus Aurelius' letters preserve a number of examples of switching from Latin to Greek, where the writer seemed to find no adequate means to render by a single Latin form the meaning that could be expressed by a Greek perfect.

The limitation of the corpus of texts where such examples of code-switching were sought to epistolography was natural, seeing that Roman writers avoided switching to

6 The exercise of translation is mentioned with approval by Quintilian, who notes: vertere Graeca in Latinum ueteres nostri oratores optimum iudicabant, "translating Greek into Latin was deemed the best by our older orators" (Inst. or. 10, 5, 3) before describing the details of this practice. On this subject, see also Pliny the Younger (Ep. 7, 9) and Cicero (De or. 1, 155).

7 Saylor 1911, 44-45. Of the two cases where Greek perfect is not rendered by the Latin present, Saylor notes: "Both are modal; one is due to sequence, the other is perhaps too free for comparison, Tim. 40c öбot

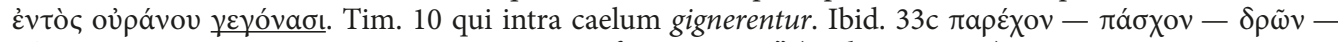

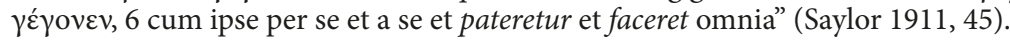


Greek in official speech altogether, and even in private conversations the use of Greek code-switching was recommended with moderation. ${ }^{8}$ A rather more delicate limitation was the choice to exclude from the discussion recognizable quotations from Greek authors where the perfect tense is used: it seemed necessary from the methodological point of view to omit these cases, as it could be argued that the quotation was solely evoked for its poetic value and associations, not because of the letter-writer's wish to evoke a verb in the perfect tense. ${ }^{9}$ This consideration accounts for the exclusion not only of the longer quotations containing a perfect form (as, e.g., Il. 9. 228-230 with $\mu \varepsilon \dot{\mu} \mu \lambda \varepsilon v$ and 5. 428-429 with $\delta \varepsilon \delta \delta o \tau a l$, both quoted in Cic. Att. 14. 13=367 Shackleton Bailey, the latter passage with a slight modification), but also of the shorter quotations where the verb in the perfect tense must, one suspects, have been one of the main reasons for the insertion of the quota-

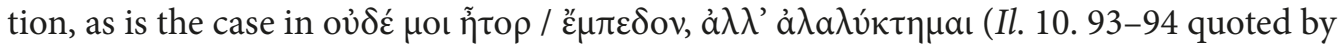
Cicero in Att. 9. 6. 4) and $\gamma \dot{\varepsilon} \gamma \eta \theta \varepsilon \delta \dot{\varepsilon} \varphi \rho \varepsilon ́ v \alpha \Lambda \eta ́ \tau \omega ~(O d .6 .106)$ quoted by Fronto in a letter to Marcus Aurelius (Aur. 1.2.2).

The quantity and the distribution of examples of Greek perfect forms vary from author to author, depending on his personal stylistic preferences and aims in each given passage, but also on the sheer bulk of the preserved corpus of letters: thus, Seneca's Letters to Lucilius contain only a small amount of Greek, while over a thousand Greek insertions are scattered over Cicero's letters. ${ }^{10}$ Among these, examples of code-switching for the sake of using the Greek perfect forms (either in isolation, or in a short syntagma in which the perfect form is central) constitute a limited group. The scarcity of examples explains why they have not been studied as a group; ${ }^{11}$ however, their number is sufficient to point to certain tendencies in Latin speakers' use of Greek perfect forms.

To start with the obvious, Greek perfects are used in cases where the author needed to emphasize in equal measure the fact that the action belonged to the past and the state resulting from this action, and when he felt that the resultative use of Latin perfect would not suffice. ${ }^{12}$ In one remarkable instance, Cicero uses the Greek perfect to describe the contemporary state of politics:

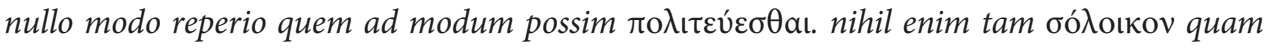
tyrannoctonos in caelo esse, tyranni facta defendi. sed vides consules, vides reliquos magis-

${ }^{8}$ On the usage of Greek in private conversation among intimate acquaintances, see Dubuisson 1992, 193. On the extent of usage of Greek in everyday conversation, see Kaimio 1979, 193, and a recent overview by Rochette 2010, 284-285.

${ }^{9}$ Cf. Dunkel 2000, 123-124 who also chooses to exclude quotations from his discussion of the use of Greek in Cicero's correspondence.

10 On Greek in Cicero, see Steele 1900 and Rose 1921 who give a useful list and overview of codeswitches to Greek; for a generalized picture, see Horsfall 1979, 84-85, especially: "Cicero's love of Greek is beyond question; the Greek in his letters shows him a master of elegant contemporary conversational idiom" (Horsfall 1979, 84).

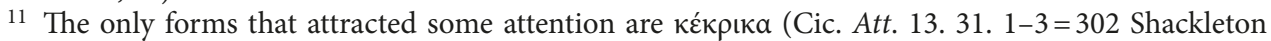
Bailey; Plin. Ep. 1. 12. 10) and $\beta \varepsilon \beta i ́ \omega \tau \alpha$ (Cic. Att. 14. $21.3=375$ Shackleton Bailey; 12. $2.1=238$ Shackleton Bailey; Sen. Luc. 12.9) that occur more than once; the use of these perfect forms will be discussed below.

12 The fact that the use of the Latin perfect to denote a given state of affairs for the most part is dependent on the context (i.e. on the interaction of the intrinsic semantic value of the Latin perfect with the exterior context) has particularly been emphasized by Pinkster 1990, 231-232; Pinkster 2015, 446-448 (cf. also Zheltova 2017, 326). Obviously, this does not include the case of defective verbs that have no present (such as odi, memini, coepi, cf. novi and credidi; Hofmann, Szantyr 1965, $318 \$ 178 \mathrm{a}$ ). 
tratus, si isti magistratus, vides languorem bonorum. [...] nec ulla interea decreta. sic enim $\pi \varepsilon \pi \mathrm{\nu} ı \varepsilon \varepsilon ́ \mu \varepsilon \theta a$ ut victos metueremus (Cic. Att. 14. $6=360$ Shackleton Bailey).

I see no way how I could take part in politics. Nothing is as absurd as the fact that the tyrantslayers are extolled to the skies and at the same time the tyrant's deeds are protected. But you see our consuls, you see the rest of the magistrates, if you can call them that, you see the inaction of good people. [...] meanwhile, nothing is decreed. Our politics have been such that we now stand in fear of those we have defeated.

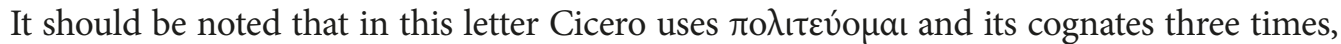
so that his choice to switch to Greek for $\pi \varepsilon \pi 0 \lambda ı \varepsilon \varepsilon \dot{\mu} \mu \varepsilon \theta \alpha$ is to a large extent motivated by the verb's terminological usage. However, from the point of view of syntax of tenses, this example is remarkable in view of the emphasis placed on the action's pertaining to the past: this nuance is particularly brought out by the use of imperfect subjunctive in the subordinate clause ut victos metueremus, which shows that in this context, Cicero perceived $\pi \varepsilon \pi \mathrm{o} \lambda \iota \varepsilon \varepsilon u ́ \mu \varepsilon \theta$ primarily as an historic tense, while using it to describe the current state of affairs.

There is a distinct preference for passive perfects over the active and the middle: among

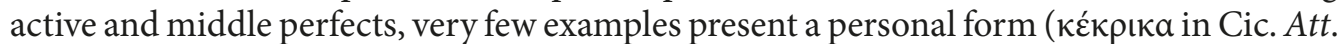

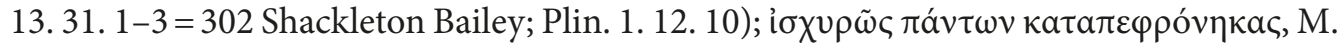

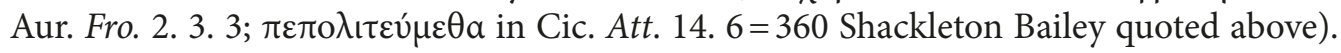
Nor is it surprising to find that passive forms are for the most part used without indication of the agent (dativus auctoris), given the tendency to use Greek perfects as a substitute for the resultative perfect in Latin, especially to denote the state that results from an action in the past; the only example of this construction occurs in Marcus Aurelius' letter to Fronto:

Sed ego orationibus his perlectis paululum misere scripsi, quod aut Lymphis aut Volcano dicar-

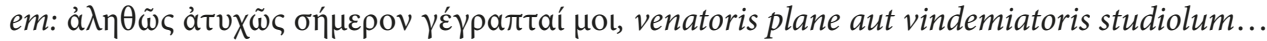
(M. Aur. Fro. 4. 5.3).

But, having read those speeches, I wrote for a little while something pitiful, fit to be offered to Water or to Vulcan (i.e. Fire - M. K.): truly, the results of what I had written today were hapless, an essay worthy of some huntsman or vintager...

In this case, while, formally, $\gamma \varepsilon \dot{\varepsilon} \gamma \rho a \pi \tau a$ í $\mu$ o is a passive construction, $\mu$ o can be interpreted both as a dativus auctoris and dativus (in)commodi: it would seem that Marcus Aurelius

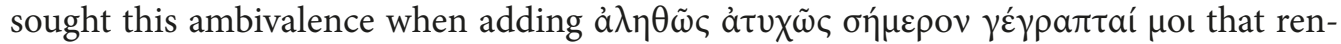
ders closely the idea of paululum misere scripsi, as the Greek expression suggests with more immediacy the idea of inspiration as an impersonal force that the writer is not fully control of.

The switch from Latin to Greek for the perfect form to describe the state of affairs, as well as the preponderance of passives among those switches, is further linked to the tendency to use denominative perfect forms, especially formed from terms or colloquial expressions. The close connection between the perfect of the denominative verb and the noun on the basis of which it is formed is particularly evident in Cicero's description of the style of his son's letter:

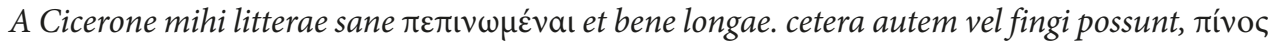
litterarum significat doctiorem (Cic. Att. 14. 7. 1-2=361 Shackleton Bailey). 
I had a letter from Cicero, quite accomplished (literally, with a fine literary vernis) and fairly long. Anything else may be falsified, but this vernis distinguishes a man of outstanding learning.

While the literary term $\pi$ ívoৎ is attested elsewhere in ancient criticism, ${ }^{13}$ the perfect participle $\pi \varepsilon \pi \iota \nu \omega \mu \varepsilon$ val used to describe a letter that cultivated this quality of style, has a shade of familiarity to it, suggesting a professional jargon shared both by Atticus and Cicero; this impression is confirmed by the occurrence of the adverb formed from the passive participle, in another passage where Cicero speaks of his son's style: cf. tandem a Cicerone tabellarius; sed mehercule litterae $\pi \varepsilon \pi \omega \omega \omega \mu \varepsilon v \omega \varsigma$ scriptae, "finally a letter-carrier from Cicero; honest to god, his letter is written in an accomplished manner" (Cic. Att. 15. 16. 1).

An even stronger colloquiality is manifest in three other passages, where Cicero uses Greek perfect forms to describe his emotional state. Thus, Cicero speaks of his pride in having helped Ariobazanes to retain his throne and of his own deeds in Cappadocia: recte $\pi \varepsilon \varphi v \sigma i ́ \omega \mu a \mathrm{l}:$ nihil est praeclarius, "I have every right to feel proud: nothing could be more glorious" (Att. 5. 20. 6=113 Shackleton Bailey), where the perfect $\pi \varepsilon \varphi v \sigma i ́ \omega \mu$ a (literally, "I am puffed up", from $\varphi v \sigma i a ́ \omega$, denominative verb formed from $\varphi \tilde{v} \sigma \alpha)$ defines his general emotional state, both evoking the past (with the suggestion that the success of each actions had contributed to his pride) and focusing on his present state. As was the case with $\pi \varepsilon \pi \iota \omega \omega \mu \varepsilon \dot{v}$ a, Cicero is making use of a popular expression that originated in the technical language (in this case, it was a medical term), but seems to have been fairly current, in its metaphoric usage, in the кoเvท́ Greek. ${ }^{14}$ In another letter, Cicero summarizes his bewil-

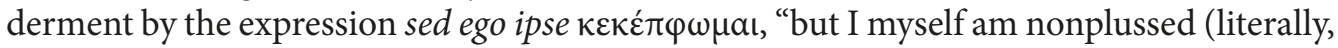
I am no better than a petrel)" (Cic. Att. 13. 40. $2=343$ Shackleton Bailey), where the verb in the perfect is derivative of $\kappa \varepsilon ́ \pi \varphi$ oৎ "stormy petrel" that can be used metaphorically for a feather-brained fellow. ${ }^{15}$

The perfect $\kappa \varepsilon \kappa \varepsilon \dot{\tau} \uparrow \omega \mu \alpha$ emphasizes the bewilderment as reaction to a given situ-

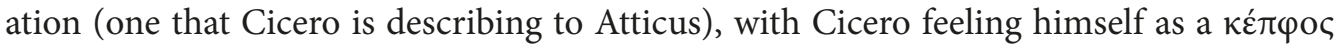
being fully conditioned by the turn of events. Finally, Cicero uses a similar perfect with colloquial overtones to describe the importance that the purchase of the land for a shrine

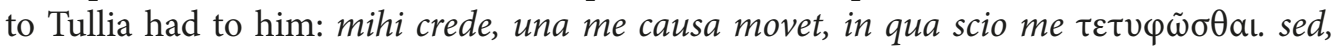
ut facis, obsequere huic errori meo, "believe me, I am moved by one cause only, in which

${ }^{13}$ Cf. the characterization of the use of plain style in Plato's dialogues by Dionysius of Halicarnassus: ö

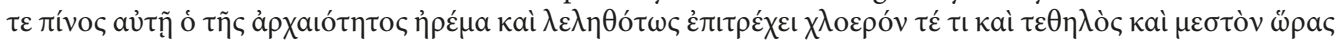
$a ̈ v \theta 0 \varsigma$ ó $v a \delta i \delta \omega \sigma \mathrm{l}$, "and there is a patina of antiquity to [Platos plain style] that gently and surreptitiously covers it, and gives to it a certain bloom, fresh and burgeoning and full of grace" (Dem. 39). Shackleton Bailey 1965-1970, VI, 218 in his note on 361, 2, 2 defines rívoৎ as follows: "In a literary context it denotes an agreeably old-fashioned quality of style [...], or, with a slightly different nuance, classical correctness without slang or neologisms".

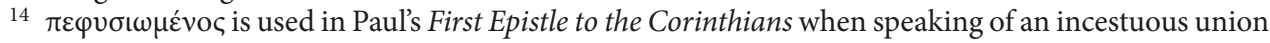

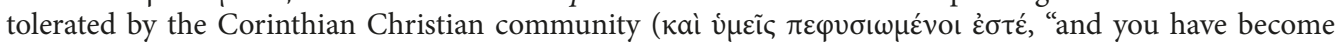
proud", 1 Cor. 5:2, word also used at 4:6 and 4:18). The expression also is mentioned by lexicographers (Hsch. $\pi$ 2139, cf. schol. in Theocr. Id. 1. 43a).

${ }^{15}$ In this metaphorical sense it was used by Aristophanes (Pax 1067 and Pl. 912), and probably

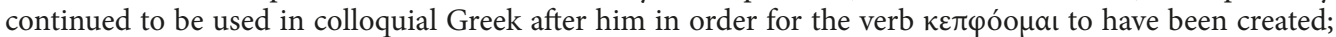

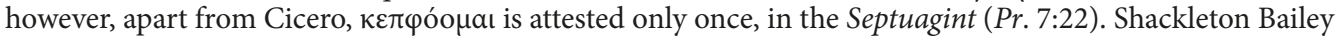

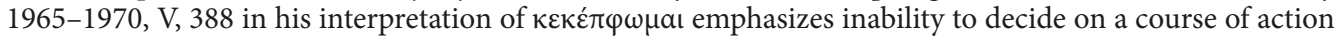

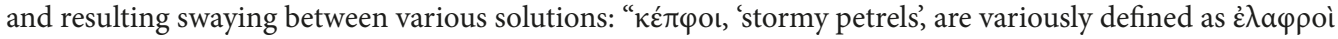

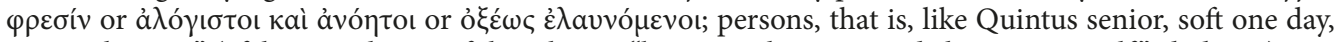
savage the next" (cf. his translation of this phrase, "but I am chopping and changing myself", ibid. 243). 
I know myself to be crazed. But please humor my delusion, as you are doing now" (Cic. Att. 12. 25. $2=264$ Shackleton Bailey). The expressive use of the perfect $\tau \varepsilon \tau u ́ \varphi \omega \mu a$ was current in Greek prose from the IV century BC on, having particularly been favored by

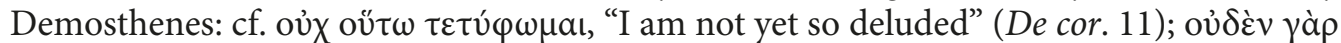

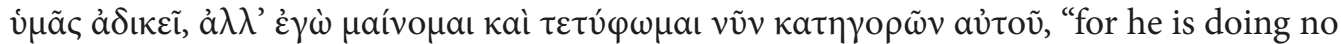
wrong by you, but it is I who am mad and deluded in accusing him now" (De fals. leg. 220);

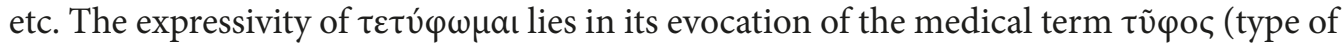
fever that manifests in a patient as a state of hebetude, cf. Hipp. De aff. int. 39; also the gloss

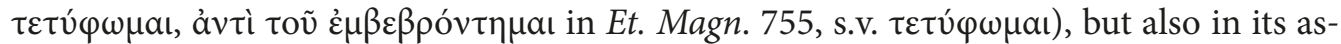
sociation with the adjective $\tau \cup \varphi \lambda$ óc. The perfect tense $\tau \varepsilon \tau \dot{v} \varphi \omega \mu$ al captures extremely well the state of delusion or obsession that makes the speaker incapable of seeing anything but the object of his obsession, and also the temporariness of this state. When referring in the following phrase to his project in Latin, Cicero denotes it with a much less expressive term error (although, of course, it can be argued that he is indicating the perspective towards this plan that he is hoping Atticus to adopt).

In each of these cases we find a short statement concerning the author's emotions (pride, bewilderment, obsession) through the use of a denominative Greek verb in the perfect tense that highlights both the state that Cicero is in, and the progressive reaching of that state. At the same time, Cicero distances himself somewhat, with a touch of irony, from his emotion ${ }^{16}$ by switching to a different language and evoking its colloquial style and popular, expressive imagery. This use of Greek in order to distance oneself from what is being said has, of course, been noticed by scholars, with some even claiming it to be one of the most important functions of code-switching. ${ }^{17}$ As regards the use of Greek perfect tense, in one example the insertion of two Greek perfect forms serves two functions at once, both describing the present situation that is rooted in the past (with the suggestion that it is irreparable) and allowing the writer to distance himself somewhat from the uncomfortable idea by expressing himself in Greek:

Collocutus sum cum Tiberio, ut mandasti, mea Livia, quid nepoti tuo Tiberio faciendum esset ludis Martialibus. Consentit autem uterque nostrum, semel nobis esse statuendum, quod consilium in illo sequamur. Nam si est artius, ut ita dicam, holocleros, quid est quod dubitemus, quin per eosdem articulos et gradus producendus sit, per quos frater eius productus sit?

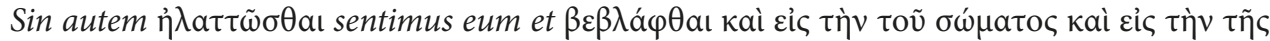

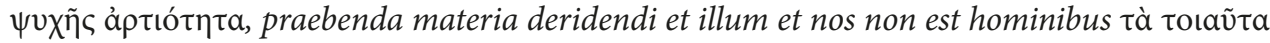

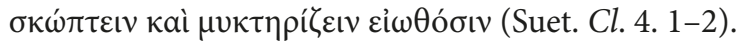

I have spoken with Tiberius, following your request, my Livia, <on the question of $>$ what is to be done with your grandson Tiberius at the games of Mars. Each of us agreed in the idea that we should decide once and for all what conduct to adopt with regard to him. For if he is of sound mind, or to put it thus, un homme complet, what gives us reason to doubt that he should be put through all the grades and steps that his brother was led through? But if we feel that he is wanting and defective in soundness both in body and in spirit, we should not

16 Cicero's tendency to switch to Greek, when speaking of emotional and personal matters, has been noted by Dunkel 2000, 128; a number of similar examples of such code-switching are collected by Adams 2004, 311-312 who adopts a more prudent and nuanced approach to the idea of Greek as the language of intimacy.

17 See, in particular, Dunkel 2000; cf. Adams 2004, 330-335. 
provide the means of ridiculing both him and us to the people who are used to scoff at and deride such things.

The question that Augustus is outlining to Livia at this point concerns Claudius' general upbringing and the best way to prepare him for the future. The first possibility, obviously one that the family would have wanted, is expressed in Latin, albeit with an insertion

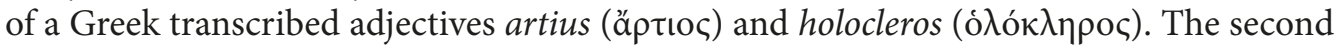
possibility, much less palatable, is expressed in Greek. The importance of the perfect tense for what Augustus is saying is evident from the separation of $\dot{\eta} \lambda \alpha \tau \tau \tilde{\omega} \sigma \theta \alpha$ from the second part of the explanation in Greek. The choice of the perfect tense emphasizes the fact that this unwelcome alternative implies a firm belief that Claudius' wit and physical state are damaged beyond hope, while the switching to Greek at this point helps Augustus to speak of the delicate issue to Livia. ${ }^{18}$ This code-switching is all the more remarkable given Augustus' ambiguous relationship with Greek, a language that, as Suetonius tells us, he admired, but never learned to write in with ease (Aug. 89). ${ }^{19}$

There remain two Greek fixed expressions consisting of a single perfect form, $\kappa \varepsilon ́ \kappa \rho \iota \kappa \alpha$ and $\beta \varepsilon \beta i ́ \omega \tau \alpha$, that seem to have had a certain currency among Latin speakers, as they appear repeatedly in a fixed form in unrelated contexts (somewhat like French expressions voilà! and c'est la vie! that have been adopted by several European languages).

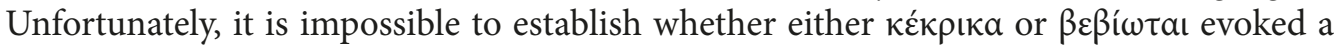
well-known context (and as such, could be labelled as quotations) or they represent a type of expression that was current in Greek and carried connotations that were absent from any possible Latin equivalent, forcing Latin speakers to switch to Greek for this particular form (and as such should be treated as tag lines or clichés). The latter approach seems more prudent. ${ }^{20}$ It is remarkable that, apart from appearing as a code-switch in epistolog-

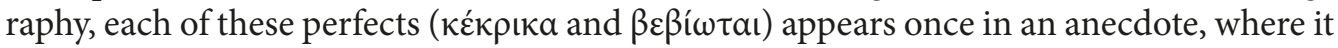
is distinguished from the body of the text as direct speech. Thus, Pliny recounts the pass-

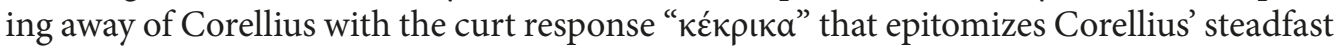
and courageous resolve to die:

Misit ad me uxor eius Hispulla communem amicum C. Geminium cum tristissimo nuntio, destinasse Corellium mori nec aut suis aut filiae precibus inflecti; solum superesse me, a quo revocari posset ad vitam. Cucurri. Perveneram in proximum, cum mihi ab eadem Hispulla Iulius Atticus nuntiat nihil iam ne me quidem impetraturum: tam obstinate magis ac magis induruisse. Dixerat sane medico admoventi cibum: Kéкрıкa, quae vox quantum admirationis in animo meo tantum desiderii reliquit (Plin. Ep. 1. 12.9-10).

His wife, Hispulla, sent our mutual friend C. Geminius to me with the saddest message that Corellius was determined to die and that he would not give in to her pleas nor to those of his daughter, and that I was the only person left who could call him back to life. I went in speed. And I was close by when Iulius Atticus, sent by the same Hispulla, announced to me that even I would not be able to achieve anything: he had so persevered more and more in

18 Cf. Adams 2004, 331-332 on this passage from Augustus' letter quoted by Suetonius: Adams views the code-switch as a form of euphemism, when dealing with delicate or unpleasant matters, that allowed to spare the other party's sensibilities.

19 See Adams 2004, 11; Rochette 2010, 284.

${ }^{20}$ On this category of Greek proverbs and proverbial-type expressions that appear in Latin texts as fixed clichés, see Adams 2004, 335-337. 
his obstinacy. He had said to the doctor who was putting food [to his lips]: 'I have decided', a word that left in my soul as much admiration for him, as longing.

Corellius speaks in Greek as, very probably, his doctor was Greek, but as noted by O. Wen-

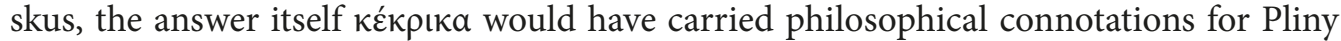

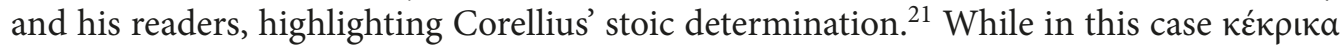
is the focal point of the story, the form could also be used in a much more neutral way,

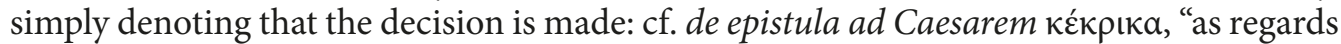
Caesar's letter, I have made up my mind" (Cic. Att. 13. 31. 1-3=302 Shackleton Bailey). Similarly, in one of the letters to Lucilius the perfect $\beta \varepsilon \beta i \omega \tau$ í is used as a mot in the anecdote of Pacuvius' rather morbid ritual that Seneca cites as an (albeit imperfect) exemplum of a day-to-day approach to life that becomes a Stoic:

Pacuvius, qui Syriam usu suam fecit, cum vino et illis funebribus epulis sibi parentaverat, sic in cubiculum ferebatur a cena ut inter plausus exoletorum hoc ad symphoniam caneretur: $\beta \varepsilon \beta i ́ \omega \tau \alpha \iota, \beta \varepsilon \beta i ́ \omega \tau \alpha$. Nullo non se die extulit. Hoc quod ille ex mala conscientia faciebat nos ex bona faciamus, et in somnum ituri laeti hilaresque dicamus, vixi et quem dederat cursum fortuna peregi.

(Sen. Luc. 12. 8-9; the verse quoted is Verg. Aen. 4. 654)

Pacuvius, who had made Syria his own by [profligate] use [of the territory], held a regular funeral rites in his own honor, with wine and funeral feasting, and would thus be carried to his bedchamber from the dining-room so that to the applause of male prostitutes the follow-

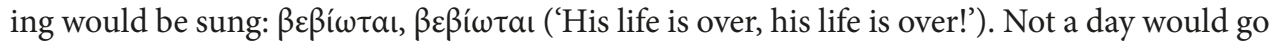
by without his being carried out this way. Let us do with a good motive, what he had done out of guilty conscience, and when retiring to bed, let us say, with joy and gladness, 'I have lived, and achieved the course that Fate had given me'.

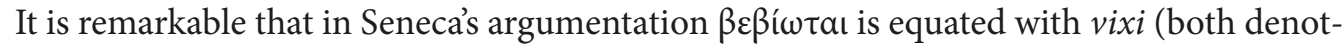
ing a completed life, in the latter case, a well-lived life). It is also worth noting that vixi is distinguished by positive connotations, illustrated by the quotation from Vergil (the idea is repeated in the next phrase of Seneca's letter, quisquis dixit 'vixi' cotidie ad lucrum surgit, "whoever has said 'I have lived', rises everyday as if it were a [personal] gain"),

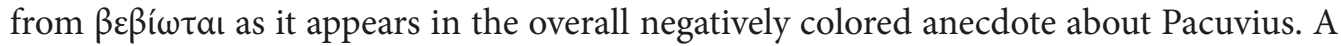

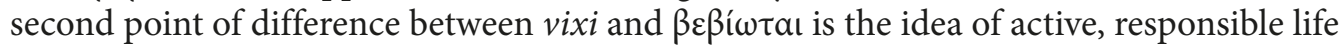
suggested by the personal Latin form and the idea of a life that one has no control over, suggested by the impersonal Greek perfect. Vixi points, of course, to the Roman funerary formula vixit (that stands euphemistically for 'he has died' or 'he is dead'), but its use here is peculiar, as it refers not so much to the completion or termination of one's life but to the wisdom of living one's life so that it could be felt as completed any day. ${ }^{22}$ As regards

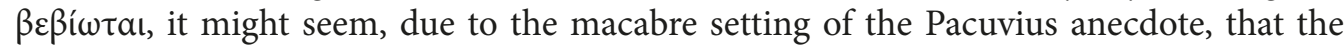

21 Wenskus 1993, 214, comparing this passage with Epictetus (2. 15. 4-6), concludes: „Außerdem scheint das inhaltsschwere ке́крıка gerade in stoischen bzw. stoisierenden Kreisen als Ausdruck des unveränderlichen Willens des wahren Philosophen gegolten zu haben“.

22 This nuance of vixi was well noticed by Nisbet and Rudd in their commentary to Horace, and it is characteristic that they chose to cite Seneca's account of Pacuvius as a parallel: "We have taken vixi on its own as the terse and sufficient pronouncement of the wise man; this is supported by Seneca's story of Pacuvius (epist. 12, 9f.)..." (Nisbet, Rudd 2004, 359 on Carm. 3. 29. 41-43). 
form might carry similar funerary associations, but a comparison with two other cases of its usage shows that this is not necessarily so:

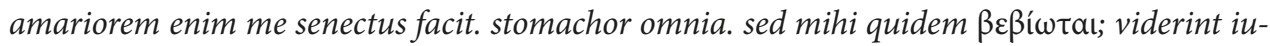
venes. tu mea curabis, ut curas (Cic. Att. 14. $21=375$ Shackleton Bailey).

Old age is making me overbitter. I am angry at everything. But my life is nearly over: let the younger people decide. You will take care of my interests, as you do now.

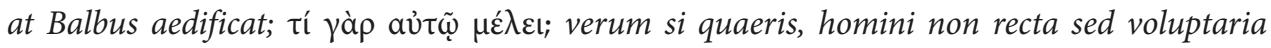
quaerenti nonne $\beta \varepsilon \beta i ́ \omega \tau \alpha$ ? (Cic. Att. 12. 2. $1=238$ Shackleton Bailey).

Balbus, on the other hand, is building: what does he care? If you wish to know the truth, with respect to a person seeking not what is right but what is pleasant, has not such a person's life been lived well?

In neither of these passages does $\beta \varepsilon \beta i ́ \omega \tau \alpha$ ı refer to a life that is literally terminated, but instead to a life that can be reviewed and seen as a whole; moreover, it should be noted that the form $\beta \varepsilon \beta i ́ \omega \tau$ a ı would not have failed to evoke $\beta$ íoc (as a notion, especially, a philosophical notion). ${ }^{23}$

Thus, an overview of Greek perfects in Roman letter-writing suggests that, apart

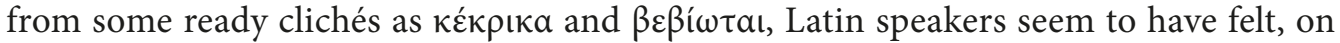
occasion and in a non-official context, an urge to switch to Greek in order to render by a single form the idea of a state of affairs resulting from an action in the past (especially in the passive, for which Greek had a synthetic form, while Latin had to use an analytical form or a periphrastic expression with habere). And while the Latin perfect could be used to express the idea of the present state resulting from a past action, ${ }^{24}$ a certain adjustment of the surrounding context was necessary in order to draw attention to the presence of this semantic nuance in the form that per se expressed simply a completed past action. The use of a Greek perfect, on the other hand, allowed Latin speakers to express that idea by means of a single form, while the very act of code-switching would draw attention to the complex semantics of the Greek perfect. This seems to have been particularly the case for denominative Greek verbs that allowed the letter-writer to emphasize in equal measure both the state of affairs and the progressive coming about of

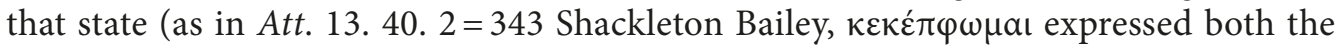

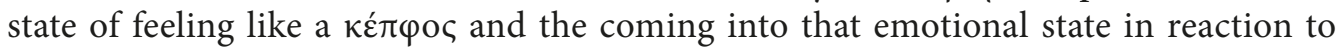
prior events). This kind of code-switching was not always possible - nor necessary, for that matter; however, it did come in handy, when the writer needed to distance himself somewhat from what he was saying, as the switching to Greek, associated in several of the analyzed examples with a certain familiarity of tone and a degree of irony, did provide that effect of distancing.

23 This semantic nuance of $\beta \varepsilon \beta$ í $\omega \tau$ ๘a seems to have been missed by Hofmann and Szantyr: „Bemerkenswert ist die Übertragung des lateinischen Gebrauchs ins Griechisch, Cic. Att. 12, 2, 1 homini non recta sed voluptaria quaerenti nonne $\beta \varepsilon \beta i \omega \tau \alpha$ l?, 14, 21, 3, da dem Griechischen ein solches Perfekt im Sinne des Nichtmehrseins von Haus aus fremd ist" (Hofmann, Szantyr 1965, $318 \$ 178 \mathrm{a}$ ).

${ }^{24}$ Cf. Hofmann, Szantyr 1965, $318 \$ 178$ a; Pinkster 2015, 447; Zheltova 2017, 326. 


\section{References}

Adams J. N. Bilingualism and the Latin Language. Cambridge, CUP, 2004.

Baratin M. Colombat B. Holtz L. (eds.) Priscien. Transmission et refondation de la grammaire de l'Antiquité aux modernes. Turnhout, Brepols, 2009.

Chantraine P. Histoire du parfait grec. Paris, Honoré Champion, 1926.

Dubuisson M. Le grec à Rome à lépoque de Cicéron, extension et qualité du bilinguisme. Annales E. S.C. 1992, 47 (1), 187-206.

Dunkel G. E. Remarks on Code-Switching in Cicero's Letters to Atticus. MH 2000, 57, 122-129.

Glück M. Priscians Partitiones und ihre Stellung in der spätantiken Schule, mit einer Beilage (Commentarii in Prisciani Partitiones medio aevo compositi). Hildesheim, Georg Olms, 1967.

Helm R. Priscianus. RE 1954, 22.2, 2328-2346.

Hofmann J. B. Szantyr A. Lateinische Syntax und Stilistik. München, C. H. Beck, 1965.

Horsfall N. Doctus sermones utriusque linguae. Échos du monde classique 1979, 23 (3), 79-95.

Kaimio J. The Romans and the Greek Language. Helsinki, Societas scientiarum Fennica, 1979.

Kaster R. Guardians of Language: The Grammarian and Society in Late Antiquity. Berkeley, Los Angeles, Oxford, University of California Press, 1997.

Lallot J. (éd., comm.) La grammaire de Denys le Thrace, traduite et annotée. $2^{\mathrm{e}}$ éd. Paris, CNRS éditions, 2003. McKay K. L. The Use of the Ancient Greek Perfect Down to the Second Century AD. BICS 1965, 12, 1-21.

Nisbet R. G. M. Rudd N. A Commentary on Horace: Odes, Book III. Oxford - New York, OUP, 2004.

Pinkster H. Latin Syntax and Semantics, trasl. by H. Mulder. London - New York, Routledge, 1990.

Pinkster H. The Oxford Latin Syntax. Vol. I: The Simple Clause. Oxford, OUP, 2015.

Rijksbaron A. The Syntax and Semantics of the Verb in Classical Greek. An Introduction. Chicago-London, University of Chicago Press, 2007.

Rochette B. Greek and Latin Bilingualism. in: E. J. Bakker (ed.) A Companion to the Ancient Greek Language. Malden MA, Oxford, Chichester, Wiley-Blackwell, 2010. 281-294.

Rose H. J. The Greek of Cicero. JHS 1921, 41(1), 91-116.

Saylor Ch. H. A Comparative Scheme of the Moods and Tenses in Cicero's Translations from the Greek. Diss. John Hopkins University. Baltimore, J.H. Furst, 1911.

Schwyzer E. Debrunner A. Griechische Grammatik auf der Grundlage von Karl Brugmanns Griechischer Grammatik. Bd. II: Syntax und syntaktische Stilistik. 5. Aufl. München, C. H. Beck, 1988.

Shackleton Bailey D. R. (ed., comm.) Cicero's Letters to Atticus. Vol. I-VII. Cambridge, CUP, 1965-1970.

Sicking C. M. J. Stork P. Two Studies in the Semantics of the Verb in Classical Greek. Leiden; New York; Köln, E. J. Brill, 1996.

Steele R. B. The Greek in Cicero's Epistles. AJPh 1900, 21(4), 387-410.

Wackernagel J. Studien zum griechischen Perfectum. In: Programm zur akademischen Preisverteilung. Göttingen, Universität Göttingen, 1904. 3-24. (=Wackernagel, J. Kleine Schriften, herausgegeben von der Akademie der Wissenschaften zu Göttingen. Bd. II. Göttingen, Vandenhoeck \& Ruprecht, 1953, 10001021).

Wackernagel, J. Vorlesungen über Syntax, mit besonderer Berücksichtigung von Griechisch, Lateinisch und Deutsch. Bd. I-II. Basel, Birkhäuser, 1926-1928.

Wenskus O. Zitatzwang als Motiv für Codewechsel in der lateinischen Prosa. Glotta 1993, 71 (3/4), 205-216. Zheltova E. V. Evidential Strategies in Latin. Hyperboreus 2017, 23 (2), 313-337. 